\title{
MICB wt Allele
}

National Cancer Institute

\section{Source}

National Cancer Institute. MICB wt Allele. NCI Thesaurus. Code C104649.

Human MICB wild-type allele is located in the vicinity of $6 \mathrm{p} 21.3$ and is approximately $16 \mathrm{~kb}$ in length. This allele, which encodes MHC class I polypeptide-related sequence B protein, is involved in cytolytic activation of natural killer cells, CD8 alpha-beta T cells, and gammadelta T cells. 